\title{
25 Research Square

\section{Hepatoprotective Effect of Costus Afer on Trace Metal Mixture Treated Rats Mediated by Regulation of Oxidative Stress Markers, Inflammatory Cytokines and Bio-Metal Chelation}

\section{Brilliance 0. Anyanwu}

University of Port Harcourt

Anthonet N. Ezejiofor

University of Port Harcourt

Ify L. Nwaogazie

University of Port Harcourt

Orish Ebere E Orisakwe ( $\nabla$ orishebere@gmail.com )

University of Port Harcourt https://orcid.org/0000-0002-5806-9858

\section{Research Article}

Keywords: Heavy metal mixture, environment, exposure, hepatotoxicity, Costus afer

Posted Date: April 26th, 2021

DOl: https://doi.org/10.21203/rs.3.rs-400513/v1

License: (c) (i) This work is licensed under a Creative Commons Attribution 4.0 International License.

Read Full License 


\section{Abstract}

Technological developments have led to exposure to various substances that are harmful to the environment and public health, including heavy metals. In the environment, these grades of metals are usually diverse mixtures shown to cause physiological, biochemical and neurological dysfunctions in humans and laboratory animals. Cadmium, Lead, and mercury have been envisaged to exhibit their hepatotoxic effects by oxidative induction damage and synthesis of reactive oxygen species (ROS). The current work evaluated the protective activity of aqueous leaf extract of Costus afer (ALECA)) on liver damage arsing from exposure to trace metal mixture (TMM): cadmium chloride $\left(\mathrm{CdCl}_{2}\right)$, lead chloride $\left(\mathrm{PbCl}_{2}\right)$, and mercury chloride $\left(\mathrm{HgCl}_{2}\right)$. Five groups of weight matched Sprague Dawley rats were treated for 90 days. Metal mixture and deionized water were used to treat the 2 groups of rats whereas the other 3 groups were treated with various doses of the ALECA through oral gavage alongside the metal mixture. Hepatic function parameters, oxidative biomarkers, inflammatory cytokines, Morphological changes and trace metals (concentrations were monitored in the liver). TMM treatment resulted in significant increase in ALT, AST, ALP, bilirubin, IL-6, MDA, but decreased albumin, total protein, IL-10, SOD, CAT and GSH levels. TMM also caused some morphological changes and increased the heavy metal ( $\mathrm{Pb}, \mathrm{Cd}$ and $\mathrm{Hg}$ ) concentrations in the liver. The leaf extract gave a reasonable protective effect on the hepatotoxicity caused by trace metal mixture - through the mechanisms of metal chelation, anti-inflammatory, and antioxidant although this depends on the dosage to the rats. ALECA may be beneficial in the management of liver toxicity.

\section{Introduction}

Trace metals occur from both natural and human activities. Their continued use in the industry, agriculture, medicine and technology has led to a great concern of safety for human health and the environment (Tchounwou et al. 2012). Metals are systemic toxic agents known to cause several organs damage seven at low exposure levels. Lead, Mercury, and Cadmium affect human organs leading to hepatotoxicity (Rana et al. 2018). These elements are ranked among the precedence metals that are of enormous concern to the public health (WHO, 2010).

Uptake and elimination of extraneous compounds are the vital functions of the liver (Anyanwu et al. 2018). Hepatotoxicity refers to impairment to the hepatocyte ensuing from overload of chemicals and exogenous compounds which include heavy metals and their metabolites (Singh et al. 2011). Owing to the dominance of these metals in our ecosystem, the long-term effect of a combination of lead, cadmium and arsenic have been studied and liver toxicity recorded by Bhattacharjee et al (2016).. Treatment of rats with $\mathrm{Pb}$ and $\mathrm{Cd}$ combination have also resulted in liver damage (Yuan et al. 2014).

Our perceptive of the unfavorable health effects of metals is based fundamentally on studies conducted on persons with rather high exposure, such as in the metal industry or in densely polluted environments. Humans are pretty exposed in their homes and workplace. There is a need to carry out further studies on the consequences of chronic environmental trace metal and their mixtures animal models that can be 
extrapolated to humans (Kentson et al. 2018). Due to the necessity of mimicking real-life situation, it becomes important to evaluate the toxic consequences of various trace metal exposures.

The chelators from modern medicine have been effective in treating the acute toxicity of metal poisoning, elimination of metal from soft tissues, and formation of non-toxic complexes. Despite their contribution in the treatment of metal poisoning, they also have some drawbacks which include toxicity issues, availability and affordability concerns. These disadvantages constitute the need to provide effective and safe pre-treatment therapy. The knowledge of the relevance of natural antidotes as chemo-preventive agents in metal poisoning being deemed as 'generally regarded as safe' GRAS, affordability and availability has gained traction recently.

Different pharmacological properties of Costus aferhas given rise to the study of its safe bioactive compounds that may show promise as drug. Protection of the liver from noxious trace metal mixtures is considered worthwhile given the importance.. The anatomical proximity of the liver to the intestines predisposes the liver to toxic assault. Hepatotoxicity is usually characterized by increased membrane permeability and changes in enzyme levels. In a hydrocarbon-mediated liver damge, there was a substantial decrease in serum ALP and AST within normal at $400 \mathrm{mg} / \mathrm{kg}$ of aqueous leaf extract of Costus afer (ALECA) compared to rat treated with $200 \mathrm{mg} / \mathrm{kg}$ of the extract through oral gavage (Ukpabi et al. 2012; Boison et al. 2019). The stem extract of Costus aferwas protective inalcohol-mediated liver damage in rats, suggesting a possible benefit in alcohol liver cirrhosis (Tonkiri et al. 2014; Boison et al. 2019).

Previous studies have also shown that aqueous leaf extract of Costus afer(ALECA) may be organoprotective(kidney and testis) in lead-mediated kidney and testis damages via antioxidant mechanisms (Tchamgoue et al. 2018, Ezejiofor and Orisakwe, 2019a; Boison et al. 2019). As much as various studies have reported on exposure of single heavy studies there remain insufficient information on the heavy metal mixtures which represent the real situation of these toxicants in various environmental matrices. Classical and synthetic metal chelators which has become the mainstay of the antidotal management of metal intoxication together with the numerous side effects are nonexistent and expensive especially in developing countries (Amadi et al 2019). This study focuses on investigatingthe hepatoprotective action of aqueous leaf extract of Costus afer (ALECA) on male albino rats exposed to trace metal mixture (TMM) of lead, cadmium and mercury.

\section{Materials And Methods}

\section{Harvesting of Costus afer}

Samples of Costus afer were collected from a farmland in the University of Port Harcourt, Rivers State, Nigeria, in an area free from air pollution due to vehicular traffic. Mr. A. O. Ozioko, who is a staff of Botany Department, University of Nigeria, Nsukka helped to verify the plant for its authenticity prior to its usage.

\section{Preparation of the Costus afer leaf extract}


Leaves of Costus afer were washed to remove sand particles, pulverized and stored. $250 \mathrm{~g}$ of the pulverized leaf samples were macerated in $500 \mathrm{ml}$ deionized water i for 24 hours amidst continuous agitations after the method of Ezejiofor and Orisakwe (2017). The mixture was shaken while the pulverized leaves pressed to obtain the extract which was stored in a refrigerator at $4^{0} \mathrm{C}$ (Anyanwu et al. 2020a). The process was repeated after every four days of treatment to obtain fresh extract to replace the redundant extract over the 90 days treatment period (Anyanwu et al. 2020a).

Determination of the aqueous leaf extract of Costus afer (ALECA) dosage

A total of 12 rats separated into four equivalent groups that received Costus afer 1000 , 2000,40005000 $\mathrm{mg} / \mathrm{kg}$ respectively and were observed for 24 hours for any change in physical features or death. At the end of the treatment, no death or change in physical features was recorded. This implied that Costus afer has no toxic effect.

To determine the dose used for this study, an assumed dose was used since the extract was confirmed to be relatively safe. Thus, we assumed the dose of $3000 \mathrm{mg} / \mathrm{kg}$ and then used $25 \%$ of the assumed dose as the low dose, $50 \%$ of the assumed dose as the medium dose and $75 \%$ of the assumed dose as the high dose.

\section{Phytochemical screening of the plant material}

The Costus afer leaves were assayed to examine the inherent phytochemical constituents using the method of Harbone, (1998); Sofowora, (2006); Trease and Evans, (2009).

\section{Animal care handling}

The study used thirty-five male albino rats that were about 8 weeks old with $100-200 \mathrm{~g}$ weights procured from the Animal House of the Faculty of Pharmacy, University of Port Harcourt, Nigeria. The study utilized the animal husbandry procedure established in previous studies by Ezejiofor and Orisakwe (2017) and Anyanwu et al. (2020b).

\section{Design of the experiment}

Five groups of seven rats each based on their weight were used for this study. The first group was as the standard control on which only deionized water was administered whereas the second group received only trace metal mixture $\left(\mathrm{PbCl}_{2}, 20 \mathrm{mg} / \mathrm{kg} ; \mathrm{CdCl}_{2}, 1.61 \mathrm{mg} / \mathrm{kg} ; \mathrm{HgCl}_{2}, 0.40 \mathrm{mg} / \mathrm{kg}\right)$ (Sigma Aldrich WGK Germany) (Institoris et al. 2006 and Anyanwu et al. 2020a). Groups 3, 4 and 5 received tracemetal mixture and aqueous leaf extract of Costus afer (ALECA) at 750, 1500 and $2250 \mathrm{mg} / \mathrm{kg}$ respectively (Anyanwu et al. 2020a). These treatments were done four times in seven days for 90 consecutive days through oral gavage.

\section{Necropsy}


After 90 days, the rats were anaesthetized with and sacrificed. The samples were collected according to the procedures recorded by Anyanwu et al. (2020a; 2020b).

\section{Preparation of liver homogenate}

Liver tissue was homogenized inbuffer ( $\mathrm{pH}$ 7.4). The supernatant was collected after centrifugation (3000 rpm for $15 \mathrm{mins}$ at $4^{0} \mathrm{C}$ ) for inflammatory and antioxidant analysis.

\section{Metal analysis}

About $6 \mathrm{ml}$ and $2 \mathrm{ml}$ of Nitric acid and perchloric acid respectively were used for the acid digestion of the liver after isolating the weighed organ. The samples were left for 30 mins after acidification before being heated at $105^{\circ} \mathrm{C}$ until digestion was completed. Whatmann filter paper Number (1) was used for filtration so as to obtain clearer samples. The solution was later made up to $15 \mathrm{ml}$ (final volume) with distilled water. All the glassware were thoroughly washed and rinsed before use. Calibration curves of $\mathrm{Pb}, \mathrm{Cd}$ and $\mathrm{Hg}$ as previously described by Anyanwu et al. (2020a; 2020b). Solar thermo elemental flame Atomic Absorption Spectrometer (Model SG 71906) was used to determine the levels of Pb, $\mathrm{Cd}$ and $\mathrm{Hg}$ at a detection limit of $<0.001 \mathrm{mg} / \mathrm{kg}$. Standard operating parameters were set and the hollow cathode lamps for $\mathrm{Pb}, \mathrm{Cd}$ and $\mathrm{Hg}$ (Model SG 71906) were employed as radiation source and fuel was air acetylene. All the samples and standard were run in duplicate.

\section{Hepatic biomarkers}

Estimation of alanine aminotransferase (ALT) and Aspartate transaminase AST

The alanine aminotransferase (ALT) and Aspartate transaminase AST activities of the liver samples were assayed employing a Randox kit (Reitman and Frankel 1975).

\section{Estimation of ALP}

The ALP function was determined with the aid of standard diagnostic kits (Randox Laboratories Ltd, UK) using the calorimetric endpoint (Klein et al., 1960).

\section{Estimation of total and direct bilirubin}

This was done using standard diagnostic kits in a calorimetric process (Randox Laboratories Ltd, UK; Jendrassic and Groff, 1938)

\section{Estimation of total protein and albumin}

This was done using a standard diagnostic kits

\section{Antioxidant analysis}

CAT activity 
CAT activity was assayed by adapting the method of Clairborne (1995).

\section{Estimation of hepatic glutathione (GSH) level}

Glutathione (GSH) level was estimated after the method of Sedlak and Lindsay (1968) .

\section{Estimation of SOD activity}

Following the method of Misra and Fridovich (1972), superoxide dismutase was determined.

\section{Lipid peroxidation marker (MDA) activity}

Following the method of Ohkawa and Ohishi (1979), the MDA was evaluated.

\section{Evaluation of Inflammatory cytokines [Interlukin-6 (IL-6) and Interlukin-10 (IL-10)]}

Enzyme-linked immunosorbent assay (ELISA) was employed. The enzyme linked immunosorbent assay kit (ELISA -Bioassay Technology Laboratory, 1713 Junjiang Inter. Bldg. 218 Ningguo Rd. Yangpu Dist. Shanghai, China) with the sensitivity of $0.052 \mathrm{ng} / \mathrm{L}$ and $1.51 \mathrm{pg} / \mathrm{ml}$ respectively as outlined in Anyanwu et al. (2020a) were used.

\section{Histopathological examination}

Tissues were soaked in $10 \%$ formaldehyde, sectioned and treated with haematoxylin and eosin H\&E. The $\mathrm{H} \& \mathrm{E}$ treated tissues were finally examined with a microscope at 200x magnification following the procedures outlined in Anyanwu et al. (2020a).

\section{Statistical analysis}

The analysis of variance (ANOVA) was applied to the sequence of observations for the purpose of comparative analysis at $5 \%$ significance. Multiple comparisons were carried out with Duncan's multiple comparison method. The principal component analysis (PCA) was employed to select the principal factors (or independent variables) for developing the multiple regression equations. In this study, the use of PCA was accomplished using XLSTAT 2016 (Nwaogazie, 2011; Anyanwu et al. 2020b).

\section{Results}

The phytoconstituents of aqueous leaf extract of Costus afer(ALECA) is shown on Table 1. 
Table 1

Quantitative phytochemical screening $(\mathrm{mg} / 100 \mathrm{~g})$ of the aqueous leaf extract of Costus afer (ALECA)

\begin{tabular}{|ll|}
\hline Chemical constituents & Content \\
\hline Alkaloids & $4.3 \pm 0.10$ \\
\hline Phenolic compounds & $1.23 \pm 0.05$ \\
\hline Saponins & $2.9 \pm 0.08$ \\
\hline Tannins & $2.72 \pm 0.11$ \\
\hline Flavonoids & $25 \pm 0.13$ \\
\hline
\end{tabular}

1. Rats treated with with the trace metal mixture TMM only, had a considerable increase in liver weight $(p<0.05)$ compared to the normal control rats (received only deionized water). Rats that received both aqueous leaf extract of Costus afer (ALECA) and trace metal mixture (TMM)

had decreased liver weight (Table 2). The absolute and relative weightsof liver of rats that received only trace metal mixture (TMM) was $9.4 \pm 1.35 \mathrm{~g}$ and $3.62 \pm 0.47 \%$ respectively while the rats administered with only deionized water had $5.08 \pm 0.95 \mathrm{~g}$ and $2.45 \pm 0.41 \%$ respectively.

Table 2

Effect of aqueous leaf extract of Costus afer on the absolute and relative weight of liver treated with trace metal mixture (TMM)

\begin{tabular}{|lcl|}
\hline Treatment & *Absolute $(\mathrm{g})$ & Relative $(\%)$ \\
\hline Deionized $\mathrm{H}_{2} \mathrm{O}$ & $5.08 \pm 0.95^{\mathrm{a}}$ & $2.45 \pm 0.41^{\mathrm{a}}$ \\
\hline $\mathrm{TMM}$ & $9.4 \pm 1.35^{\mathrm{c}}$ & $3.62 \pm 0.47^{\mathrm{c}}$ \\
\hline $\mathrm{TMM}+750 \mathrm{mg} / \mathrm{kg} \mathrm{ALECA}$ & $8.48 \pm 1.13^{\mathrm{bc}}$ & $3.52 \pm 0.42^{\mathrm{bc}}$ \\
\hline $\mathrm{TMM}+1500 \mathrm{mg} / \mathrm{kg} \mathrm{ALECA}$ & $8.36 \pm 0.52^{\mathrm{bc}}$ & $3.15 \pm 0.17^{\mathrm{bc}}$ \\
\hline $\mathrm{TMM}+2250 \mathrm{mg} / \mathrm{kg}$ ALECA & $7.86 \pm 0.22^{\mathrm{b}}$ & $3.06 \pm 0.08^{\mathrm{b}}$ \\
\hline $\begin{array}{l}\text { *Values }=\text { Mean } \pm \text { SD, N }=5 ., \text { data with different superscripts }(\mathrm{a}, \mathrm{b}, \mathrm{c}) \text { are significantly different from } \\
\text { each other }(p<0.05), \text { data with the same superscripts are not significantly different; TMM = Trace } \\
\text { metal mixture }\end{array}$ & \\
\hline
\end{tabular}

The tests for liver function were done to evaluate the likely protective role of Costus afer treatment from metal mixture exposure. Treatment with trace metal mixture (TMM)caused significant elevation in aspartate aminotransferase, alanine aminotransferase and alkaline phosphatase levels, bilirubin (total and direct), and a decrease in total protein and albumin, whereas the rats that received both aqueous leaf extract of Costus afer (ALECA) and trace metal mixture (TMM) showed reduction in the liver enzyme markers and a rise in total protein and albumin in comparison to metal mixture-treated albino rats 
(Fig. 1). The aspartate aminotransferase, alanine aminotransferase and alkaline phosphatase, total bilirubin, direct bilirubin, total protein and albumin levels in rats treated with only trace metal mixture (TMM) were significantly different $(172 \mu / \mathrm{l}, 77.8 \mu / \mathrm{l}, 222.2 \mu / \mathrm{l}, 32.6 \mathrm{mg} / \mathrm{dl}, 15.2 \mathrm{mg} / \mathrm{dl}, 43.8 \mathrm{~g} / \mathrm{l}, 25.4 \mathrm{~g} / \mathrm{l}, p$ $<0.05$ ) respectively, from the groups that received both aqueous leaf extract of Costus afer (ALECA) and trace metal mixture (TMM).

Figure 2 is the parallel coordinates plot showing clustering of liver function parameters interaction in different treatment groups. The Fig consists of three classes; class 1 (gp 1 and 5), class 2 (gp 2 and 3), and class 3 (gp 4). The factor loading of liver function variables on significant principal components which was done sequel to the Varimax rotation is presented in Table 3 whereas the correlation plot is shown in Fig. 3. An illustration of the differentiation of parameters and the interactions among liver function parameters in different groups is depicted in Fig. 4. A 3-component system showing $95.35 \%$ of total variance was obtained after statistical principal component analysis.

The co-ordinate plot of liver function parameters showing the association between the variables consists of 3 classes. The result showed that class 1 rats had high total protein and albumin levels with low aspartate aminotransferase, alanine aminotransferase and alkaline phosphatase, total bilirubin and direct bilirubin,, while class 2 rats had high aspartate aminotransferase, alanine aminotransferase and alkaline phosphatase, total bilirubin and direct bilirubin levels with low total protein and albumin levels. Class 3 rats were of the intermediate class showing that they had midrange values for all the liver function parameters.

The Principal component analysis (PCA) provided a better interpretation of the data, having grouped the connected variables as one. The male albino rats administered with trace metal mixture (TMM) of $\mathrm{Pb}, \mathrm{Cd}$ and $\mathrm{Hg}$, seven principal factors (F1-F7) explained $100 \%$ cumulative variations in the liver function parameters. The first two components (PC1 and PC2) accounted for more than $92 \%$ of total variance, while PC3 gave rise to only $2.80 \%$ of the total variance. Factor $1(\mathrm{~F} 1)$ had Eigen value > unity explaining $87.34 \%$ of total variation of the data set and was regarded as being significant, while factors 2 and 3 ( $F 2$ and F3) had Eigen values < unity explaining 7.95\% of the total variation. (Anyanwu et al. 2020a).

Strong positive correlations $(\geq 0.88$ ) were perceived between these parameters (aspartate aminotransferase, alanine aminotransferase and alkaline phosphatase, total bilirubin and direct bilirubin) whereas a weak association $(r=0.6617)$ was observed between the Total protein and albumin. Also, both factors had negative correlations with aspartate aminotransferase, alanine aminotransferase and alkaline phosphatase, total bilirubin and direct bilirubin which is an indication that a reduction in total protein and albumin would likely lead to an increase in aspartate aminotransferase, alanine aminotransferase and alkaline phosphatase, total bilirubin and direct bilirubin and vice versa. All the variables were printed in bold in PC1 (Table 2) whereas aspartate aminotransferase had the highest loading on PCl after Varimax rotation. The principal components were extracted with the aid of a 3D graphing software to plot the correlated variables. 
Table 3

Loadings of liver function variables on significant principal components after Varimax rotation

\begin{tabular}{|llll|}
\hline Liver function parameter & *PC1 & PC2 & PC3 \\
\hline $\mathbf{s}$ & & & \\
\hline aspartate aminotransferase (U/L) & $\mathbf{0 . 9 1 0 5}$ & 0.0017 & 0.0280 \\
\hline alanine aminotransferase (U/L) & $\mathbf{0 . 9 4 4 3}$ & 0.0023 & 0.0129 \\
\hline alanine phosphatase (U/L) & $\mathbf{0 . 9 0 7 1}$ & 0.0020 & 0.0036 \\
\hline total bilirubin & $\mathbf{0 . 9 1 9 2}$ & 0.0075 & 0.0004 \\
\hline direct bilirubin (mg/dl) & $\mathbf{0 . 9 2 5 8}$ & 0.0008 & 0.0093 \\
\hline total protein (g/l) & $\mathbf{0 . 8 0 0 8}$ & 0.0787 & 0.1166 \\
\hline ALBUMIN(g/l) & $\mathbf{0 . 7 0 5 9}$ & 0.2677 & 0.0250 \\
\hline Eigen value & 6.1136 & 0.3607 & 0.1958 \\
\hline Variability (\%) & 87.3368 & 5.1532 & 2.7973 \\
\hline Cummulative (\%) & 87.3368 & 92.4900 & 95.2873 \\
\hline *Bold figures are highly correlated coefficients; and thus, the principal factors. AST = aspartate \\
$\begin{array}{l}\text { aminotransferase, ALT = alanine aminotransferase, ALP = alanine phosphatase, T.BIL = total bilirubin, } \\
\text { D.BIL = direct bilirubin, T.Protein = total protein }\end{array}$ \\
\hline
\end{tabular}

Variables (axes F1 and F2: 92.49\%)

An assessment of the inflammatory status after treatment with trace metal mixture TMM was done by evaluating the pro- and anti-inflammatory cytokines level in the liver. The co-treatment using Costus afer significantly decreased the levels of pro- and also increased $(p<0.05)$ the anti- inflammatory cytokines (IL-6 and IL-10) in the liver tissue in comparison to in the trace metal mixture TMM-treated group (Fig. 5), suggestive of anti-inflammatory activity of aqueous leaf extract of Costus afer (ALECA). The pro- and anti-inflammatory cytokine levels (IL- 6 and IL-10 respectively) of rats administered with the trace metal mixture TMM only was significantly different $(61.8 \mathrm{Pg} / \mathrm{g}$ tissue and $14.7 \mathrm{Pg} / \mathrm{g}$ tissue, $p<0.05)$ from the inflammatory cytokines seen in rats co-treated with Costus afer.

The oxidative status in the hepatocyte subsequent to the metal mixture treatment using the lipid peroxidation marker, MDA level was evaluated. The 90-day treatment which was done with the following metal mixture in the following dosage $\mathrm{PbCl}_{2}-20 \mathrm{mg} / \mathrm{kg}, \mathrm{CdCl}_{2}-1.61 \mathrm{mg} / \mathrm{kg}, \mathrm{HgCl}_{2}-0.40 \mathrm{mg} / \mathrm{kg}$ body weight induced oxidative reaction in the organ (liver tissue). The MDA level increased significantly ( $p<$ 0.05 ) in the hepatocyte of trace metal mixture TMM -treated rats in comparison to those of the normal control group (Fig. 6). A significant decrease in oxidant level was observed in the rats treated with Costus afer and metal mixture compared to those treated with only the metal mixture. 
With respect to how the treatment affects the non-enzymatic glutathione (GSH) and enzymatic superoxide dismutase and catalase (SOD and CAT) activities in the liver tissue. Treatment with trace metal mixture TMM resulted a significant decrease $(p<0.05)$ in glutathione and superoxide dismutase and catalase levels in comparison with control. Rats that received aqueous leaf extract of Costus afer (ALECA) plus trace metal mixture TMM had elevated levels of glutathione and superoxide dismutase and catalase in comparison to rats that received only trace metal mixture TMM. $\mathrm{s}$

\section{Heavy metal concentration on the liver of the rat samples}

The concentration of trace metals (lead, cadmium and mercury) in the liver were notably elevated ( $p<$ 0.05 ) in the liver of the rats treated with the trace metal mixture TMM- in comparison to the control (Table 4). Treatment of rats with aqueous leaf extract of Costus afer (ALECA) plus trace metal mixture TMM resulted in significant reduction in trace metals (lead, cadmium and mercury) levels in comparison to rats that received only trace metal mixture TMM In addition, the group exposed to the trace metal mixture TMM only, had the highest level of trace metals (lead $=90.992 \pm 13.284$, cadmium $=0.78 \pm 0.133$ and mercury $=0.305 \pm 0.0439$ ) in comparison to the control group. Pearson's rank correlation analyses indicate the inter-trace metal relationship among trace metals in liver of rats showed strong positive correlation ( $r>0.90$ ) between metals such as: $\mathrm{Pb}$ and $\mathrm{Cd}, \mathrm{Pb}$ and $\mathrm{Hg}$, as well as $\mathrm{Cd}$ and $\mathrm{Hg}$. All correlations were significant at $p<0.01$ (Fig. 7).

Table 4

Levels of trace metals (mg/kg) in the liver

\begin{tabular}{|llll|}
\hline Treatment & Cadmium (Cd) & Mercury $(\mathrm{Hg})$ & Lead $(\mathrm{Pb})$ \\
\hline Deionized $\mathrm{H}_{2} \mathrm{O}$ (only) & $<0.001 \pm 0.000^{\mathrm{a}}$ & $<0.001 \pm 0.000^{\mathrm{a}}$ & $0.392 \pm 0.552^{\mathrm{a}}$ \\
\hline $\mathrm{TMM}$ (only) & $0.782 \pm 0.133^{\mathrm{c}}$ & $0.305 \pm 0.039^{\mathrm{c}}$ & $90.992 \pm 13.284^{\mathrm{c}}$ \\
\hline $\mathrm{TMM}+750 \mathrm{mg} / \mathrm{kg} \mathrm{ALECA}$ & $0.143 \pm 0.046^{\mathrm{b}}$ & $0.051 \pm 0.020^{\mathrm{b}}$ & $31.007 \pm 6.017^{\mathrm{b}}$ \\
\hline $\mathrm{TMM}+1500 \mathrm{mg} / \mathrm{kg} \mathrm{ALECA}$ & $0.033 \pm 0.024^{\mathrm{a}}$ & $0.009 \pm 0.001^{\mathrm{a}}$ & $8.857 \pm 4.849^{\mathrm{a}}$ \\
\hline $\mathrm{TMM}+2250 \mathrm{mg} / \mathrm{kg}$ ALECA & $0.003 \pm 0.002^{\mathrm{a}}$ & $0.001 \pm 0.001^{\mathrm{a}}$ & $3.500 \pm 1.141^{\mathrm{a}}$ \\
\hline $\begin{array}{l}\text { *Values are expressed as (Mean } \pm \mathrm{SD}) . \text { Values in the same column with different superscripts are } \\
\text { significantly different from each other }(p<0.05) \text { and those with the same superscripts in the same } \\
\text { column are not significantly different; TMM }=\text { Trace metal mixture }\end{array}$ \\
\hline
\end{tabular}

\section{Histopathology of the liver}

The liver sections of six different groups were sectioned and presented in (Fig. 8 (G1), (G2), (G3), (G4), and (G5) representing groups treated with deionized $\mathrm{H}_{2} 0$, metal mixture (MM), $(M M+750 \mathrm{mg} / \mathrm{kg} A L E C A$, $\mathrm{MM}+1500 \mathrm{mg} / \mathrm{kg}$ ALECA, and MM+2250 mg/kg ALECA.

\section{Regression Model Development}


XLSTAT 2016 software was employed for the model development in this study. Lead, Cadmium, Mercury, and ALECA were considered as the input data and were used for the calibration of the model using multiple linear regressions. Zero coefficients for $x_{2}$ and $x_{3}$ were observed as outputs and thus subsequent calibrations were done without the 3 constant parameters (input data).. In other words, $y$ is made a function of ALECA variable for a given set of the heavy metal variables namely: Lead, Cadmium, and Mercury. A plot of catalase concentration vs ALECA concentration was modelled using linear, quadratic and exponential options (Table 5). The $\mathrm{R}^{2}$, MSE and RMSE values were determined and shown in Table 6 for the process.

For verification of he calibrated models, the observed model was compared with predicted model on the liver catalase level (Fig. 9) with corresponding $\mathrm{R}^{2}=0.935$.

The quadratic and exponential models for the liver catalase level was $\mathrm{R}^{2}$, MSE and RMSE of $(0.935,1.513$ and 1.230$)$ and $(0.880,1.022$ and 1.011$)$ respectively. The linear model best predicted the process with $\mathrm{R}^{2}$, MSE and RMSE values of. $0.935,0.760$ and 0.872 respectively. A repetition of the regression models was done for other liver parameters and based on $\mathrm{R}^{2}$, MSE and RMSE, the best models were selected. To verify the calibrated models, it was important to compare observed against predicted liver catalase level with corresponding $\mathrm{R}^{2}=0.999$. The modeled liver catalase values for ALECA plus TMM treated groups at $0 \mathrm{mg} / \mathrm{kg}, 750 \mathrm{mg} / \mathrm{kg}, 1500 \mathrm{mg} / \mathrm{kg}$ and $2250 \mathrm{mg} / \mathrm{kg}$ were $2.680,4.770,6.860$ and 8.950, while the observed values were $2.360,5.640,6.080$ and 9.180 respectively. Similarly, the verification was equally done on other parameters in the liver.. These models could help predict the residual values of liver function parameters, antioxidant profile and inflammatory cytokines in the liver of male albino rats at any treatment dose using ALECA to a high precision provided the levels of lead, cadmium, and mercury remains constant as considered in this work.

Table 5

Regression models of catalse in

\begin{tabular}{|lllll|}
\hline Type of Model & Equation & $\mathrm{R}^{2}$ & MSE & RMSE \\
\hline Exponential & $y=2.801 \mathrm{e}^{0.000 \mathrm{x}}$ & 0.880 & 1.022 & 1.011 \\
\hline *Linear & $y=0.002 x+2.68$ & 0.935 & 0.760 & 0.872 \\
\hline Quadratic & $y=-8 \mathrm{E}-08 x^{2}+0.003 x+2.635$ & 0.935 & 1.513 & 1.230 \\
\hline NB: * The model with the best fit. & & & \\
\hline $\begin{array}{l}\text { A replication of regression models was done on other biomarkers and the best with respect to } \mathrm{R}^{2}, \mathrm{MSE}^{-} \\
\text {and RMSE values was selected and summarized as shown in the Table 6 below; }\end{array}$ & \\
\hline
\end{tabular}


Table 6

Model equations for antioxidant biomarkers, inflammatory cytokines and other test parameters in the liver

\begin{tabular}{|c|c|c|c|c|c|}
\hline Biomarkers & Type of Model & Model Equations & $\mathrm{R}^{2}$ & MSE & RMSE \\
\hline SOD & Quadratic & $\begin{array}{l}y=8 \mathrm{E}-08 x^{2}+7 \mathrm{E}-05 x+ \\
0.237\end{array}$ & 0.999 & 0.000 & 0.011 \\
\hline GSH & Quadratic & $\begin{array}{l}y=1 \mathrm{E}-07 x^{2}+0.000 x+ \\
0.814\end{array}$ & 0.999 & 0.000 & 0.018 \\
\hline MDA & Quadratic & $y=3 \mathrm{E}-08 x^{2}-0.000 x+0.645$ & 0.996 & 0.001 & 0.025 \\
\hline IL-6 & Quadratic & $y=4 \mathrm{E}-06 x^{2}-0.032 x+62.33$ & 0.996 & 5.618 & 2.370 \\
\hline IL-10 & Exponential & $y=13.98 e^{0.000 x}$ & 0.991 & 5.387 & 2.321 \\
\hline AST & Quadratic & $y=-9 \mathrm{E}-06 x^{2}-0.013 x+171.7$ & 0.999 & 1.152 & 1.073 \\
\hline ALT & Linear & $y=-0.021 x+80.32$ & 0.978 & 14.904 & 3.861 \\
\hline ALP & Exponential & $y=222.6^{e-2 E-0 x}$ & 0.996 & 7.730 & 2.780 \\
\hline T. Bilirubin & Quadratic & $y=-8 \mathrm{E}-07 x^{2}-0.007 x+32.75$ & 0.998 & 0.450 & 0.671 \\
\hline D. Bilirubin & Exponential & $y=15.53 e^{-5 E-0 x}$ & 0.995 & 0.174 & 0.417 \\
\hline T. Protein & Quadratic & $\begin{array}{l}y=2 \mathrm{E}-06 x^{2}+0.006 x+ \\
43.72\end{array}$ & 0.999 & 0.128 & 0.358 \\
\hline Albumin & Quadratic & $\begin{array}{l}y=-7 \mathrm{E}-07 x^{2}+0.007 x+ \\
25.56\end{array}$ & 0.995 & 0.512 & 0.716 \\
\hline \multicolumn{6}{|c|}{$\begin{array}{l}\text { Where } y=\text { concentration of the parameter analyzed, } x=\text { Costus afer dose, MSE = Mean Squared Error, } \\
\text { RMSE = Root Mean Squared Error, AST = aspartate aminotransferase, ALT = alanine aminotransferase, } \\
\text { ALP = alanine phosphatase, T.BIL = bilirubin(total), D.BIL = bilirubin (direct), T.Protein = total } \\
\text { protein(total), SOD = superoxide dismutase, GSH = reduced glutathione, MDA = malondialdehyde, IL-6 } \\
=\text { interleukin- } 6 \text {, and IL-10 = interleukin-10 }\end{array}$} \\
\hline
\end{tabular}

\section{Discussion}

According to Jarup (2003), most health challenges can be attributed totrace metals such as lead, cadmium, and mercury. These metals have also been associated infertility, neurotoxicity, osteoporosis, diverse organ failures in humans (Yuan et al. 2014; Youness et al. 2012; Jang and Hoffman, 2011; ). The liver helps in the body metabolism and excretion and hence their susceptibility to the adverse effects of foreign compounds (Anyanwu et al. 2018). Given the ubiquity of metals, some researchers have investigated the effects of chronic exposure to low doses of a mixture of, cadmium, and mercury, and therefore, posited that long term exposure to trace metal mixture even at low affected the liver of the rats adversely (Hamdy et al 2018, Mumtaz et al. 2019). 
Majority of the actions of can be attributed to its The inherent antioxidant properties in Costus afer could be the basis for its action and such on which the bioactive compounds for the immense medicinal properties emanate. The alkaloids, saponins, flavonoids, tannins, and phenols, are the phytoconstituents on the leaf extracts of Costus afer and are seen to be responsible for its biological activity. Flavonoids are water soluble polyphenolic compounds with fifteen atoms that are antioxidant in nature (Kurhekar, 2018) (Ezejiofor and Orisakwe, 2017). Natural phenolic compounds have antioxidant, and anti-inflammatory effects. Furthermore, tannins are water-soluble polyphenolic compounds within plants of secondary metabolism and are usually of two classes : the hydrolysable and condensed tannins (Haslam, 1998; Ezejiofor and Orisakwe, 2017). Their solutions are acidic with a characteristic astringent taste; they are also known to have strong antimicrobial activities in addition to other physiological effects which help to enhance blood clotting, as well as anti-hypertensive, anti-hyperlipedemic and immunomodulatory (Wang and Xue, 2010). Saponins are glycosides that are usually foamy in nature and has good medicinal value owing to their therapeutic action. Desai et al. 2009 reported that they help to protect plants from pathogenic attacks giving rise to their antimicrobial activity (). Alkaloids are nitrogenous compounds which are used as supplements, ingredients, supplements and for medical and pharmaceutical purposes (Ziegler and Facchini, 2008; Kurek, 2019). ).

A significant increase $(p<0.05)$ was observed in liver weights treated with the trace metal mixture TMM (only) in comparison to the control rats. However, a significant decrease weight (absolute and relative) was observed in the samples administered with aqueous leaf extract of Costus afer (ALECA) $(750,1500$ and $2250 \mathrm{mg} / \mathrm{kg}$ ) respectively in a dose-dependent manner in corroboration with the study of Bhattacharjee et al. (2016) who reported a marked elevation in the weight of the liver in rats treated with a trace metal mixture of $\mathrm{Pb}, \mathrm{Cd}$ and As. Kluwe (1981), Simmoni et al. (1995) and Orisakwe et al. (2004) further highlighted that increase or decrease in weights of organs after treatment with a chemical substance suggest toxicity. Hence, this indicates that the liver could be a target organ for heavy metal mixture toxicity. increased organ weight observed in the present work corroborates the work of Ahmad et al. (2007). This current study indicates that the aqueous leaf extract of Costus afer (ALECA) may be hepatoprotective.

The significant increment $(p<0.05)$ seen in the rats received tracemetal mixture TMM with respect to ALT, AST, ALP, total and direct bilirubin levels which formed the markers of injury to the hepatocyte could be arise from increased membrane permeability and cell loss due to membrane oxidation (Iniaghe et al. 2008; Ramachandran and Jaeschke 2018). Liver cell death (hepatocellular necrosis) or the membrane lesions increase the AST and ALT serum levels; flow into the bloodstream from the liver, in line with an increase in enzyme levels of metal mixture intoxicated rats. These observations indicate cell loss and integrity loss of functional cellular membranes in the liver in accordance with the studies of Zhang et al. 2018and Ramachandran and Jaeschke 2018. increased level of bilirubin is another marker of abnormal liver function (Kang 2013). The liver is a chemical laboratory of the body involved in oxidation and metabolic conversion of fatty acid, production of cholesterol and phospholipids and the elimination of specific classes of serum lipoprotein (Kio et al. 2018). Decreased total protein and albumin levels evident 
in rats treated with trace metal mixture TMM only could be as a result of inhibition of protein synthesis and metabolism (Yousuf 2002), which gave rise to hepatotoxicity (Nagao and Sata 2010).

Many previous studies described trace metals as immune-suppressors that result in elevated levels of TNF-a, II-1 $\beta$ and IL-6(pro-inflammatory cytokines). The elevated level of pro-inflammatory cytokine (IL-6) in this study may be due to heightened production of reactive oxygen species (Gao 2012; Guyot et al. 2015). Oxidative stress could be associated with an excessive production of the pro-inflammatory cytokines (Gao 2012). The concomitant administration of aqueous leaf extract of Costus afer (ALECA) and trace metal mixture TMM resulted in dose dependent reduction in levels of pro-inflammatory cytokine (IL-6) and increase in anti-inflammatory cytokine IL-10. Inflammation is caused by several factors, such as a group of secreted polypeptide called cytokine which control host responses to lesions, some are antiinflammatory cytokines, while function as pro-inflammatory cytokines (Dinarello 2010; Niederreiter and Tilg 2018). An elevation in the pro-inflammatory cytokine (IL-6) as well as a decrease in the antiinflammatory cytokine (IL-10) were observed in the rats exposed to trace metal mixture TMM only. These effects were alleviated upon administration of aqueous leaf extract of Costus afer (ALECA) in a dosedependent manner suggestive of anti-inflammatory potency of aqueous leaf extract of Costus afer (ALECA).

Elevated levels of antioxidant enzymes was seen in rats that received aqueous leaf extract of Costus afer (ALECA)plus trace metal mixture in comparison to those that received only trace metal mixture TMM which may suggest that aqueous leaf extract of Costus afer (ALECA) is an antioxidant and hepatoprotective.. This observation is in corroboration with work of Ezejiofor and Orisakwe (2017). Superoxide dismutase is the first defense interval for the conversion of superoxide radical anion to the production of free radicals involved in hydrogen peroxide, whereas catalase serve as the second antioxidant protection mechanism by reducing hydrogen peroxide to oxygen and water (Younus, 2018). Thus, aqueous leaf extract of Costus afer (ALECA) increased antioxidant enzymes levels which is in agreement with the previous study protective effects of Costus afer on the liver by Ezejiofor and Orisakwe (2017).

Despite the fact that the exact mechanism of the metal mixture toxicity is unclear, the observations in this study indicates that treatment with trace metal mixture TMM elicits reactive oxygen species (ROS) generation and impairment cellular antioxidant capacity. This could result in an imbalance between free radical species and the body's resistance against cellular damage (Koivula and Eeva 2010). Therefore, supplementation of antioxidant molecules would be exogenously beneficial in cell antioxidant protection to neutralize heavy metal poisoning. Aqueous leaf extract of Costus afer (ALECA) contains antioxidant phytochemicals such as phenolics and flavanoids (Ezejiofor et al.2017). This study has shown the protective effect of aqueous leaf extract of Costus afer (ALECA) over trace metal mixture TMM -induced toxicity in rats.

Malondialdehyde, a marker of lipid peroxidation, showed a substantial increase $(p<0.05)$ in the liver of rats that received trace metal mixture TMMin comparison with groups that received aqueous leaf extract 
of Costus afer (ALECA) plus trace metal mixture TMM. Malondialdehyde is a marker used to measure the level of oxidative stress in an organism (Singh et al. 2014). A similar finding revealed an elevation in lipid peroxidation in the liver after metal poisoning (Ezejiofor and Orisakwe 2017). This suggests that peroxidative injury may be involved in the development of complications of severe heavy metal toxicity.

The significant decrease in trace metals namely lead, cadmium and mercury following administration of aqueous leaf extract of Costus afer (ALECA) is prominent. Chelation of these trace metals by a phytoconstituent may be a plausible mode of action notwithstanding that actual mechanism remain largely unknown.. Only recently some researchers have opined that mopping of free radicals and chelation of metal chelation are essential features in management of oxidative stress(Policegoudra et al. 2010, Jomova and Valko 2011; Sarpong-Kumankomah et al. 2018). There is a need for further study in this regard to ascertain the actual route of metal elimination.

Pearson's rank correlations of trace metals lead, cadmium, and Mercury in the liver show strong significant relationships $(r>0.90)$ between cadmium and lead $(r=0.940, p<0.05, n=18)$, Mercury and lead $(r=0.982, p<0.05, n=18)$, Mercury and Cadmium $(r=0.960, p<0.05, n=18)$ in the liver. This strong association signifies a close physiological connection (Krebs et al., 2014). The strongest association was observed between liver Mercury and liver Lead. This relationship between these trace metals could as a result of the similarity of their oxidative states which makes them exhibit similar chemical properties.

Certain histological changes, such as hepatocyte necrosis and inflammation and severe dysplasia of hepatocytes, were observed in the rats that received trace metal mixture in comparison to to the rats that received only deionized water. Hepatic necrosis, inflammation and cytoplasmic swelling are common symptoms of liver damage (Butler et al 2018). The effect of the Costus aferwas observed in the rats cotreated with it at a dose of 750,1500 , and $2250 \mathrm{mg} / \mathrm{kg}$. Whereas the rats which received low dose aqueous leaf extract of Costus afer (ALECA) plus trace metal mixture showed hepatocyte necrosis and cytoplasmic swelling, higher doses of aqueous leaf extract of Costus afer(ALECA) plus trace metal mixture showed mild cytoplasmic swelling and mild hepatocyte inflammation. The dose dependent histomorphological protection of aqueous leaf extract of Costus afer (ALECA) against trace metal mixture mediated damage may confer on ALECA a beneficial role

\section{Conclusion}

Trace metal mixture exposure may be of significant health effect arising from oxidative damage, inflammation and distortion of histoarchitecture of the liver in rat model. The observed attenuation of destructive effects of TMM by effects tended to be attenuated by the aqueous leaf extract of Costus afer (ALECA) which could proffer some hope as an alternative remedy and circumvent the major drawbacks of notable chelators: increase in toxicity, inaccessibility and high-priced associated with modern medicine. Therefore, Costus afer could be a potential hepatoprotective agent.

\section{Declarations}




\section{Acknowledgement}

This work was partly supported by the World Bank Research Fund for Africa Centre of Excellence in Oilfield Chemicals Research (ACE-CEFOR), University of Port Harcourt. We will also like to thank Goodluck Anyanwu for helping to typeset this work.

Ethical Approval: The protocol for the experiment was approved by the University of Port Harcourt Research Ethics Committee and the reference number UPH/CEREMAD/REC/04 was assigned.

Consent to Participate: Not applicable

Consent to Publish: All authors have given their consent for publication

Authors Contributions BOA: Data curation, Bench work and draft manuscript preparation; ANE: supervision and bench work; ILN: data analysis and modeling and OEO: conceptualization, supervision and manuscript preparation

Funding: $\mathrm{BOA}$ received tuition waiver from World Bank in the course of $\mathrm{PhD}$ her training

Competing Interests: Authors confirm that there was no conflict of interest

Availability of data and materials: All data have been provided

\section{References}

1. Ahmad N, Majumder S, Miah MA, Uddin MJ (2007) Effects of edible fats and oils on the body weight gain and on weights of some selected organs in rats removing the impact of unequal feed intake. Bangla J Vet Med 5:107-10.

2. Amadi, C.N., Offor, S.J., Frazzoli, C. and Orisakwe, O.E., 2019. Natural antidotes and management of metal toxicity. Environmental Science and Pollution Research, 26(18), pp.18032-18052.

3. Anyanwu B, Ezejiofor A, Igweze Z, Orisakwe 0 (2018) Heavy metal mixture exposure and effects in developing nations: an update. Toxics 6 (4):65.

4. Anyanwu, B. O., Orish, C. N., Ezejiofor, A. N., Nwaogazie, I. L., and Orisakwe, O. E. (2020a).

Neuroprotective effect of Costus afer on low dose heavy metal mixture (lead, cadmium and mercury) induced neurotoxicity via antioxidant, anti-inflammatory activities. Toxicology Reports, 7, 1032-1038.

5. Anyanwu, B. O., Orish, C. N., Ezejiofor, A. N., Nwaogazie, I. L., and Orisakwe, O. E. (2020b). Protective Effect of Costus afer Aqueous Leaf Extract (CALE) on Low-Dose Heavy Metal Mixture-Induced Alterations in Serum Lipid Profile and Hematological Parameters of Male Wistar Albino Rats. Journal of Toxicology, 2020.

6. Bhattacharjee T, Bhattacharjee S, Choudhuri D (2016) Hepatotoxic and nephrotoxic effects of chronic low dose exposure to a mixture of heavy metals-lead, cadmium and arsenic. International J Pharm, Chem \& Biol Sci 6(1):39-47. 
7. Boison, D., Adinortey, C. A., Babanyinah, G. K., Quasie, O., Agbeko, R., Wiabo-Asabil, G. K., and Adinortey, M. B. (2019). Costus afer: A Systematic Review of Evidence-Based Data in support of Its Medicinal Relevance. Scientifica, 2019.

8. Butler, D.C., Lewin, D.N. and Batalis, N.I., 2018. Differential Diagnosis of Hepatic Necrosis Encountered at Autopsy. Academic forensic pathology, 8(2), pp.256-295.

9. Chung KT, Wong TY, Wei Cl, Huang YW, Lin Y (1998) Tannins and human health: a review. Crit Rev in Food Sci and Nutri 38(6):421-64.

10. Clairborne A (1995) Activity in: Handbook of methods for oxygen radical Research.

11. Desai SD, Desai DG, Kaur H (2009) Saponins and their biological activities. Pharma Times 41(3):136.

12. Dinarello CA (2010) Anti-inflammatory agents: present and future. Cell 140(6):935-50.

13. Ezejiofor AN, Orisakwe OE (2017) Evaluation of Protective Effect of Aqueous Leave Extract of Costus afer on Female Albino Wistar Rats Exposed to Lead Acetate. EC Pharm and Toxicol 4(2): 75-92.

14. Ezejiofor AN, Orisakwe OE (2019a) Nephroprotective effect of Costus afer on lead induced kidney damage in albino rats. International journal of physiology, pathophysiology and pharmacology 11(2):36.

15. Ezejiofor AN, Orisakwe OE (2019b) The protective effect of Costus afer Ker Gawl aqueous leaf extract on lead-induced reproductive changes in male albino Wistar rats. JBRA Assisted Reproduction 23(3):215.

16. Ezejiofor AN, Udowelle NA, Orisakwe OE (2017) Nephroprotective and antioxidant effect of aqueous leaf extract of Costus Afer Ker gawl on cyclosporin-a (Csa) induced nephrotoxicity. Clin Phytosci 2(1):11.

17. Gao B (2012) Hepatoprotective and anti-inflammatory cytokines in alcoholic liver disease. J Gastro and Hepat 27:89-93.

18. Guyot, E., Solovyova, Y., Tomkiewicz, C., Leblanc, A., Pierre, S., El Balkhi, S., and Coumoul, X. (2015). Determination of heavy metal concentrations in normal and pathological human endometrial biopsies and in vitro regulation of gene expression by metals in the Ishikawa and Hec-1b endometrial cell line. PloS one, 10(11), e0142590.

19. Hamdy, S.M., Shaban, A.M., Aziz, Y.S.A., Mahmoud, A.M., Moemen, L.A.A., Ibrahim, W.M. and Gad, N.S., 2018. Ameliorative Role of Jania Rubens Alga Against Toxicity of Heavy Metal Polluted Water in Male Rats. Policy, 2(2), pp.38-46.

20. Harborne J B (1998) Phytochemical methods. Chapman and Hall, London, p.113.

21. Haslam E (1998) Practical polyphenolics: From structure to molecular recognition and physiological action. Cambridge UK: Cambridge University Press 9810-9883.

22. Hättenschwiler, S., and Vitousek, P. M. (2000). The role of polyphenols in terrestrial ecosystem nutrient cycling. Trends in ecology \& evolution, 15(6), 238-243. 
23. Iniaghe OM, Malomo SO, Adebayo JO (2008) Hepatoprotective effect of the aqueous extract of leaves of Acalypha racemosa in carbon tetrachloride treated rats. J Med Plants Res 2(10):301-5.

24. Institóris L, Kovács D, Kecskemeti-Kovacs I, Lukács A, Szabó A, Lengyel Z, Papp A, Nagymajtényi L, Dési I (2006) Immunotoxicological investigation of subacute combined exposure with low doses of $\mathrm{Pb}, \mathrm{Hg}$ and $\mathrm{Cd}$ in rats. Acta Biol Hungarica ;57(4):433-9.

25. Jang DH, Hoffman RS (2011) Heavy metal chelation in neurotoxic exposures. Neurologic clinics 29(3):607-22.

26. Järup, L. (2003). Hazards of heavy metal contamination. British medical bulletin, 68(1), 167-182.

27. Jenrassik L, Groff P (1938) Quantitative determination of total and direct bilirubin. Biochem Z 297:81-5.

28. Jomova K, Valko M (2011) Advances in metal-induced oxidative stress and human disease. Toxicol 283(2-3):65-87.

29. Kang KS (2013) Abnormality on liver function test. Ped Gastro, Hepatol \& Nutri 16(4):225-32.

30. Kenston SS, Su H, Li Z, Kong L, Wang Y, Song X, Gu Y, Barber T, Aldinger J, Hua Q, Li Z (2018) The systemic toxicity of heavy metal mixtures in rats. Toxicolo Res 7(3):396-407.

31. Kio, A.D., Saraswati, T.R. and Yuniwarti, E.Y.W., 2018. The Effect of Red Fruit Oil (Pandanus conoideus) to the Histophysiology of Rat (Rattus norvegicus) Liver Exposed to Cigarette Smoke. Biosaintifika: Journal of Biology \& Biology Education, 10(1), pp.125-130.

32. Klein B, Read PA, Babson LA (1960) Effects of Ocimum basilicum on tissue antioxidant pathways in normal and streptozotocin-diabetic rats. Clin. Chem6: 269-275.

33. Kluwe WM (1981) Renal function tests as indicators of kidney injury in subacute toxicity studies. Toxicol and Applied Pharm 57(3):414-24.

34. Koivula MJ, Eeva T (2010) Metal-related oxidative stress in birds. Environ Pol 158(7):2359-70.

35. Krebs N, Langkammer C, Goessler W, Ropele S, Fazekas F, Yen K, Scheurer E (2014) Assessment of trace elements in human brain using inductively coupled plasma mass spectrometry. $J$ Trace Elements in Med and Biol 28(1):1-7.

36. Kurek J (2019) Introductory Chapter: Alkaloids-Their Importance in Nature and for Human Life. InAlkaloids-Their Importance in Nature and Human Life. IntechOpen.

37. Kurhekar, J. V. (2018). Antimicrobial medicinal plants as effective natural bioresources. Phytochemistry: Volume 2: Pharmacognosy, Nanomedicine, and Contemporary Issues, 185.

38. Liu Z, Li P, Zhao D, Tang H, Guo J (2011) Anti-inflammation effects of Cordyceps sinensis mycelium in focal cerebral ischemic injury rats. Inflammation 34(6):639-44.

39. Misra HP, Fridovich I (1972) The role of superoxide anion in the autoxidation of epinephrine and a simple assay for superoxide dismutase. J Biol Chem 247(10):3170-5.

40. Mumtaz, S., Ali, S., Khan, R., Andleeb, S., Ulhaq, M., Khan, M.A. and Shakir, H.A., 2019. The protective role of ascorbic acid in the hepatotoxicity of cadmium and mercury in rabbits. Environmental Science 
and Pollution Research, 26(14), pp.14087-14096.

41. Nagao Y, Sata M (2010) Serum albumin and mortality risk in a hyperendemic area of HCV infection in Japan. J Virology 7(1):375.

42. Niederreiter L, Tilg H (2018) Cytokines and fatty liver diseases. Liver Research 2(1):14-20.

43. Nwaogazi IL (2011) Probability and Statistics for Science and Engineering Practice (3rd ed.). Enugu, Nigeria: De- Adroit Innovation

44. Ohkawa H, Ohishi N, Yagi K (1979) Assay for lipid peroxides in animal tissues by thiobarbituric acid reaction. Analytical Biochem 95(2):351-8.

45. Orisakwe OE, Husaini DC, Afonne OJ (2004) Testicular effects of sub-chronic administration of Hibiscus sabdariffa calyx aqueous extract in rats. Repro Toxicol 18(2):295-8.

46. Policegoudra RS, Rehna K, Rao LJ, Aradhya SM (2010) Antimicrobial, antioxidant, cytotoxicity and platelet aggregation inhibitory activity of a novel molecule isolated and characterized from mango ginger (Curcuma amada Roxb.) rhizome. J Biosci 35(2):231-40.

47. Ramachandran A, Jaeschke H (2018) Oxidative stress and acute hepatic injury. Current opinion in Toxicol 7:17-21.

48. Rana MN, Tangpong J, Rahman MM (2018) Toxicodynamics of lead, cadmium, mercury and arsenicinduced kidney toxicity and treatment strategy: a mini review. Toxicol Reports 5:704-13.

49. Reitman S, Frankel S (1975) A colorimetric method for the determination of serum glutamic oxalacetic and glutamic pyruvic transaminases. American journal of clinical pathology 28(1):56-63.

50. Sarpong-Kumankomah S, Gibson MA, Gailer J (2018) Organ damage by toxic metals is critically determined by the bloodstream. Coordination Chem Reviews 374:376-86.

51. Sedlak J, Lindsay RH (1968) Estimation of total, protein-bound, and nonprotein sulfhydryl groups in tissue with Ellman's reagent. Analytical Biochem 25:192-205.

52. Simmons JE, Yang RS, Berman E (1995) Evaluation of the nephrotoxicity of complex mixtures containing organics and metals: advantages and disadvantages of the use of real-world complex mixtures. Environ Health Perspectives 103(1):67-71.

53. Singh A, Bhat TK, Sharma OP (2011) Clinical Biochemistry of Hepatotoxicity. J Clinic Toxicol 4(0001):1-9

54. Singh Z, Karthigesu IP, Singh P, Rupinder KA (2014) Use of malondialdehyde as a biomarker for assessing oxidative stress in different disease pathologies: a review. Iranian J Public Health 43(3):716.

55. Sofowora A (2006) Medicinal Plants and Traditional Medicine in Africa.

56. Tchamgoue AD, Tchokouaha LR, Tsabang N, Tarkang PA, Kuiate JR, Agbor GA (2018) Costus afer protects cardio-, hepato-, and reno-antioxidant status in streptozotocin-intoxicated wistar rats. BioMed Research International 2018 (2018):1-9.

57. Tchounwou PB, Yedjou CG, Patlolla AK, Sutton DJ (2012) Heavy metal toxicity and the environment. In: Mol, Clin and Environ Toxicol 101:133-164. Springer Basel. 
58. Tonkiri A, Essien ES, Akaninwor JO (2014) Evaluation of hepatoprotective and in vivo antioxidant activity of the methanolic stem extract of Costus afer (bush cane) in alcohol induced liver cirrhosis in rats. Journal of Biological and Food Science Research 3(3):29-34.

59. Trease GE, Evans WC (1996) Pharmacognosy, 4th Edition, W.B. Sounders,USA,.243-283.

60. Ukpabi C F, Agbafor K N, Ndukwe O K, Agwu A NS (2012) Phytochemical composition of Costus afer extract and its alleviation of carbon tetrachloride-Induced hepatic oxidative stress and toxicity. International Journal of Modern Botany 2(5):120-6.

61. WANG, R.B. and XUE, C.H., 2010. Progress in Studies on Physiological Activities of Tannins in China [J]. Journal of Yulin University, 2.

62. World Health Organization (WHO) (2010) WHO I Ten chemicals of major public health concern.

63. Younus, H., 2018. Therapeutic potentials of superoxide dismutase. International journal of health sciences, 12(3), p.88.

64. Yoousuf MB (2002) Effect of high dietary intake of nickel in the West African dwarf goat. Ghana J Agricl Sci 35(1):147-51

65. Youness ER, Mohammed NA, Morsy FA (2012) Cadmium impact and osteoporosis: mechanism of action. Toxicol Mech and Meth 22(7):560-7.

66. Yuan G, Dai S, Yin Z, Lu H, Jia R, Xu J, Song X, Li L, Shu Y, Zhao X (2014) Toxicological assessment of combined lead and cadmium: acute and sub-chronic toxicity study in rats. Food and Chem Toxicol 65:260-8.

67. Zhang C, Wang N, Xu Y, Tan HY, Li S, Feng Y (2018) Molecular mechanisms involved in oxidative stress-associated liver injury induced by Chinese herbal medicine: An experimental evidence-based literature review and network pharmacology study. Int J Mol Sci 19(9):2745.

68. Ziegler J, Facchini PJ (2008) Alkaloid biosynthesis: metabolism and trafficking. Annu. Rev. Plant Biol 59:735-69.

\section{Figures}




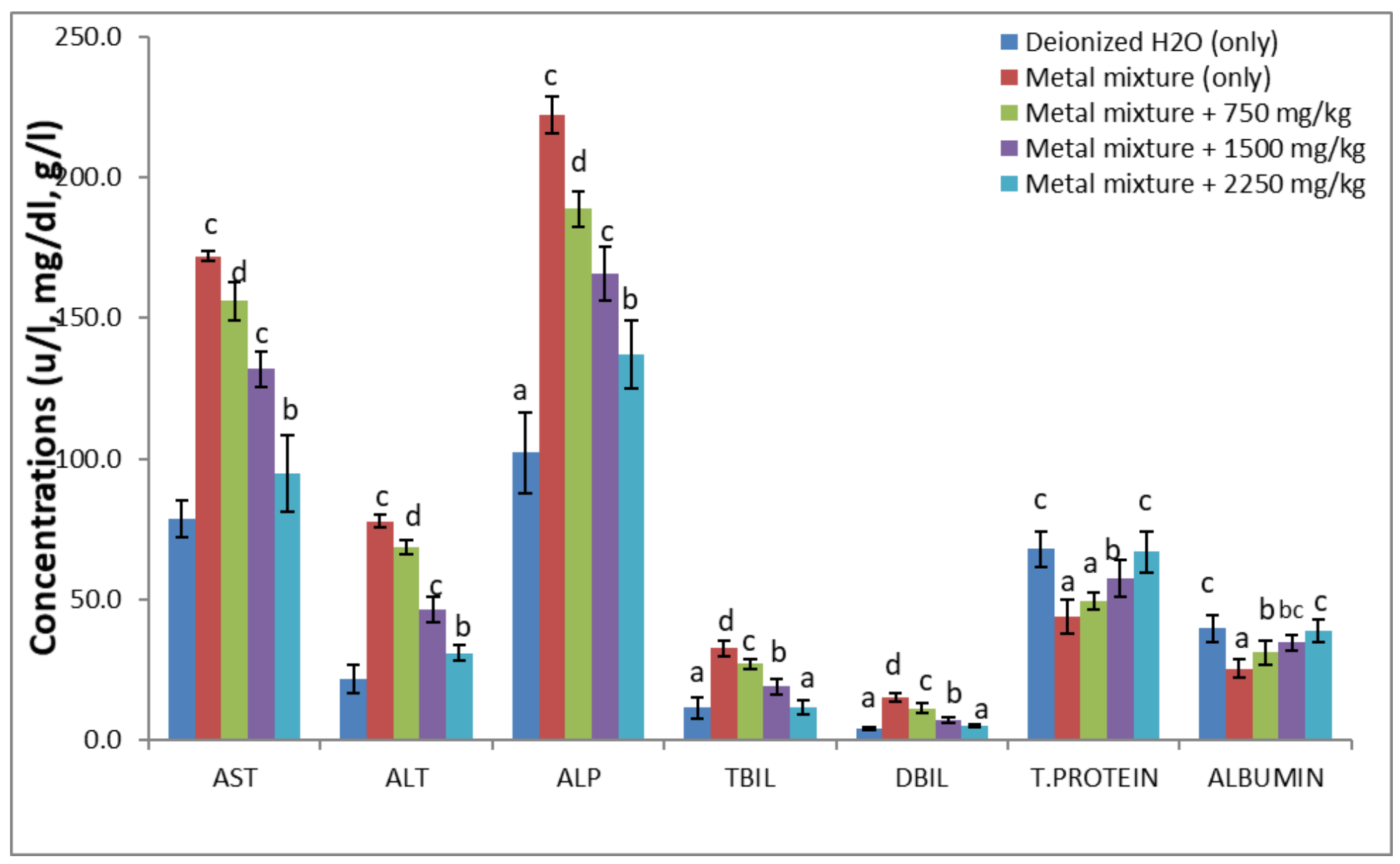

\section{Figure 1}

Effect of Costus afer extract on serum hepatic enzymes of male albino rats treated with metal mixture. Values with different superscripts $(a, b, c, d)$ are significantly different from each other $(p<0.05)$, while those with the same superscripts are not significantly different. T.Protein $=$ total protein, $\mathrm{TBIL}=$ total bilirubin,AST = aspartate aminotransferase, ALP = alanine phosphatase, ALT = alanine aminotransferase, $\mathrm{DBIL}=$ direct bilirubin, 


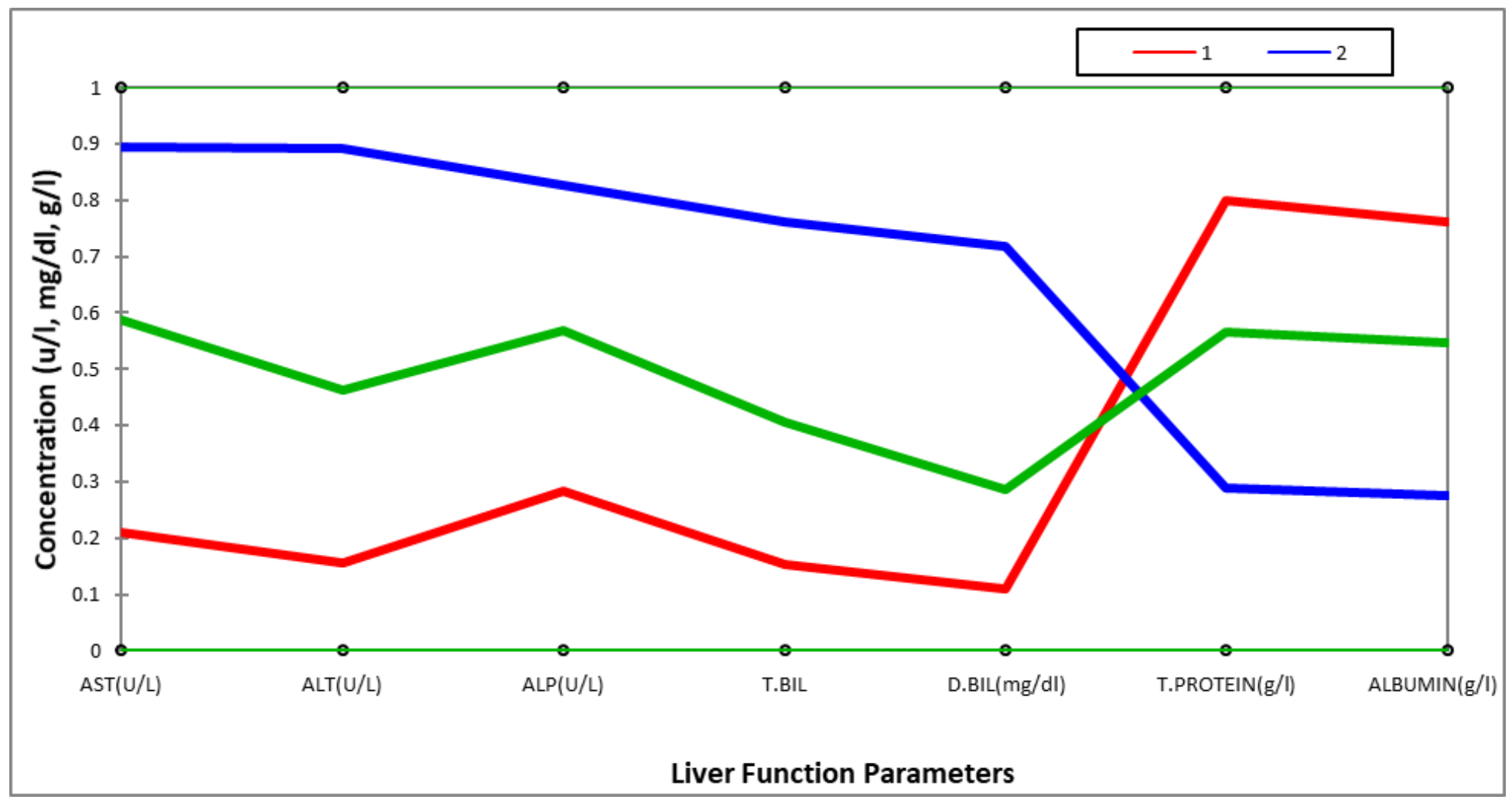

\section{Figure 2}

Plot of clusters of liver function parameters interaction in groups; T.Protein = total protein , TBIL = total bilirubin,AST = aspartate aminotransferase, ALP = alanine phosphatase, ALT = alanine aminotransferase, $\mathrm{DBIL}=$ direct bilirubin, 


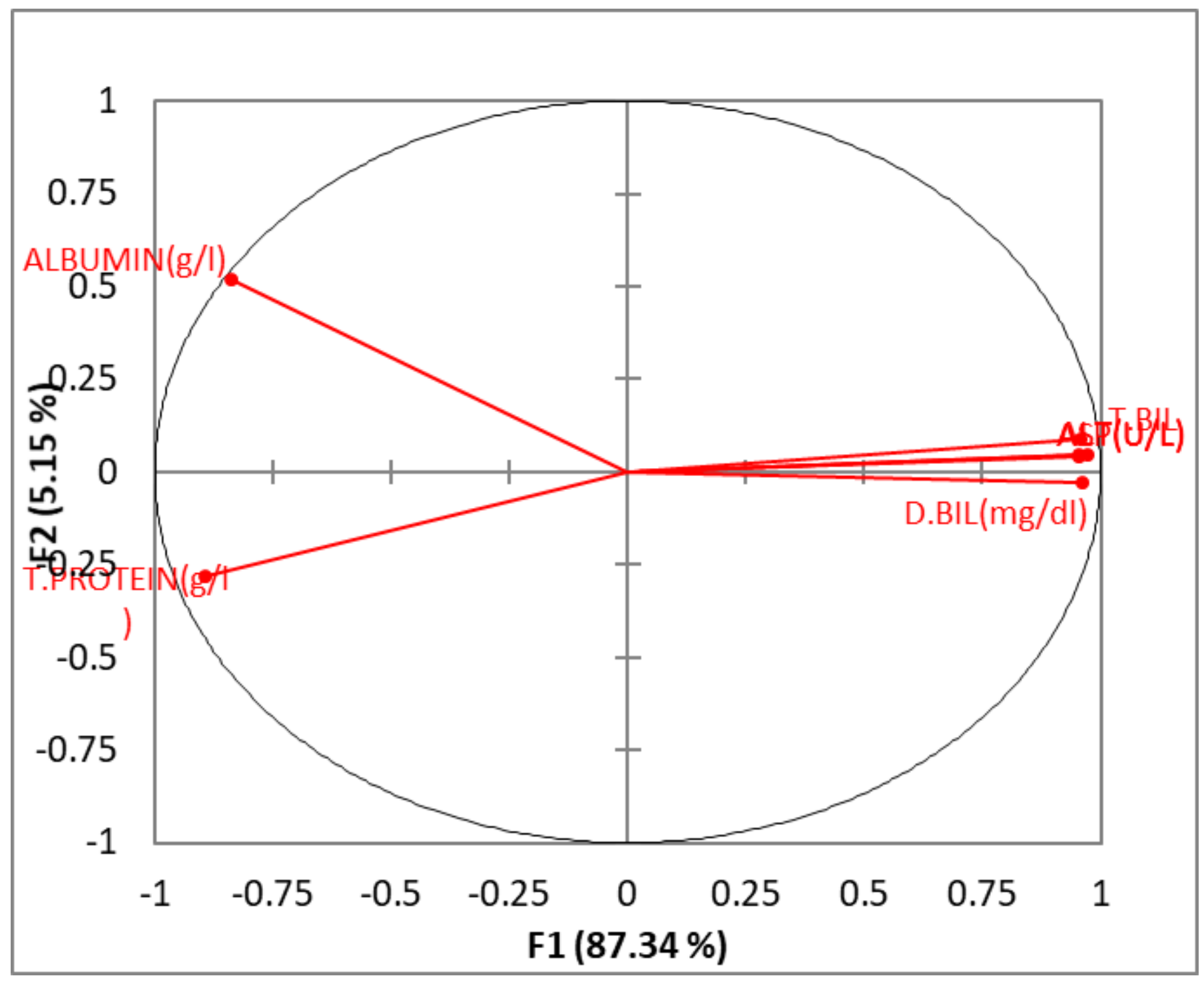

Figure 3

Correlation plot of liver function parameters on male albino rats against the generated factors ( $F 1$ and F2). T.Protein = total protein, $\mathrm{TBIL}=$ total bilirubin, $\mathrm{AST}=$ aspartate aminotransferase, $\mathrm{ALP}=$ alanine phosphatase, $\mathrm{ALT}=$ alanine aminotransferase, $\mathrm{DBIL}=$ direct bilirubin, 


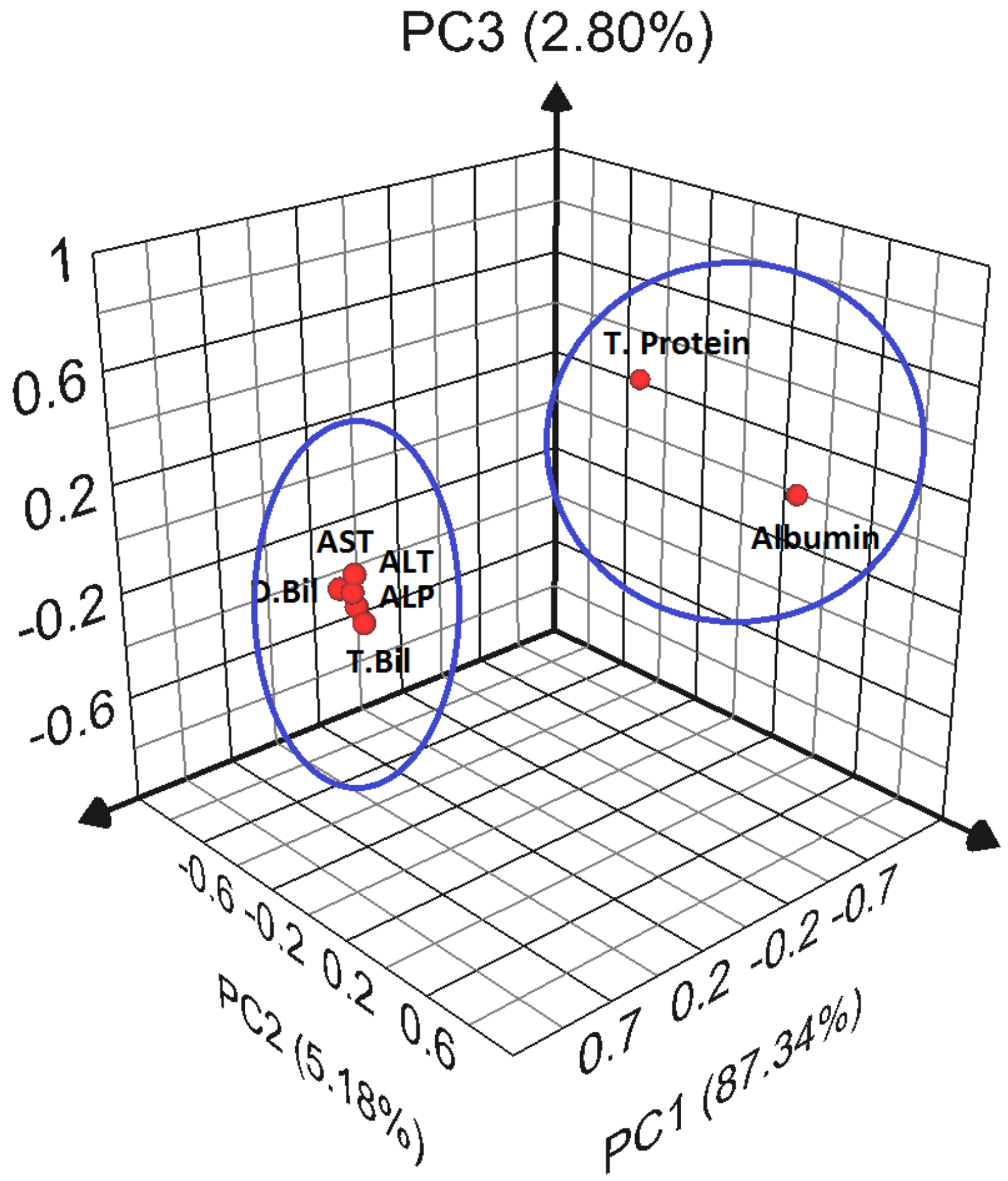

Figure 4

Score plot showing the differentiation of parameters associated with interactions among liver function parameters in different groups. A three-component system explaining $95.35 \%$ of total variance was observed after PCA. AST = aspartate aminotransferase, ALT = alanine aminotransferase, ALP = alanine phosphatase, T.BIL= total bilirubin, D.BIL = direct bilirubin, T.Protein = total protein 


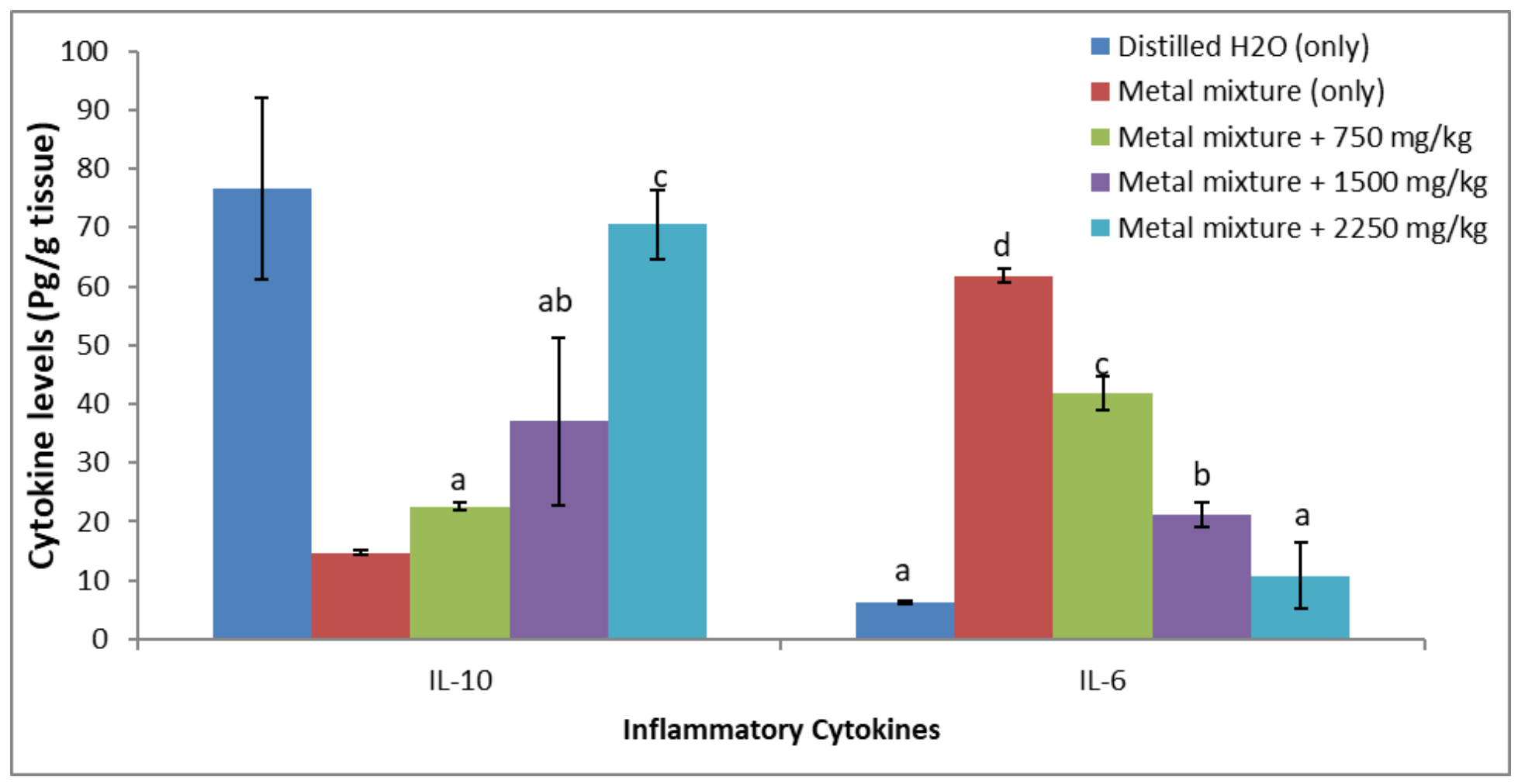

Figure 5

Effect of Costus afer on anti-inflammatory cytokines (interlukin-10 (IL-10) and proinflammatory cytokines interlukin-6 (IL-6) on liver of male albino rats treated with heavy metal mixture. Values with different superscripts $(a, b, c)$ are significantly different from each other $(p<0.05)$, while those with the same superscripts are not significantly different.

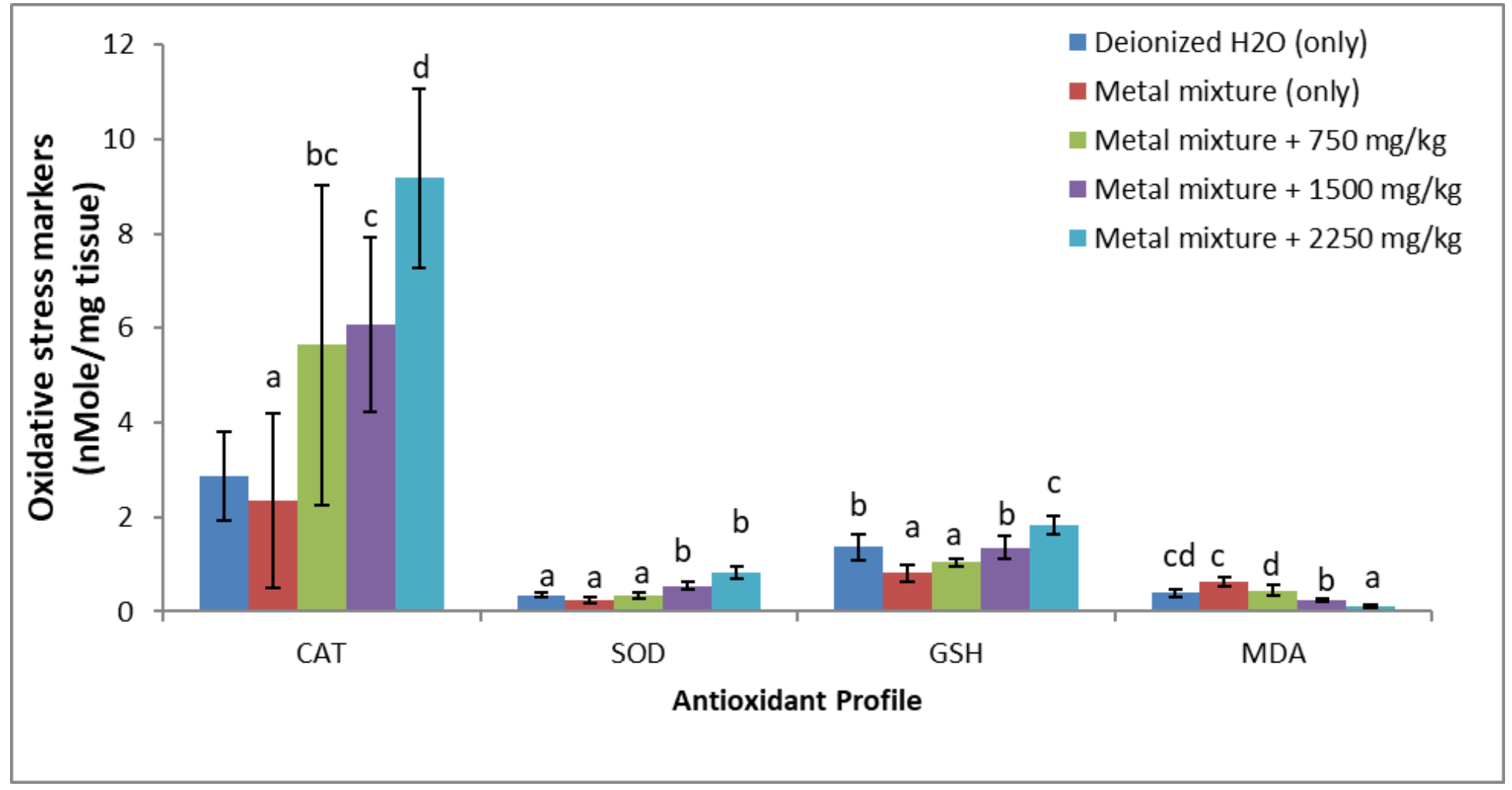


Figure 6

Effects of Costus afer on oxidative stress markers of the liver of male albino rats treated with metal mixture. Values with different superscripts $(a, b, c, d)$ are significantly different from each other $(p<0.05)$, while those with the same superscripts are not significantly different. CAT = catalase, SOD = superoxide dismutase, $\mathrm{GSH}$ = reduced glutathione, and MDA = malondialdehyde

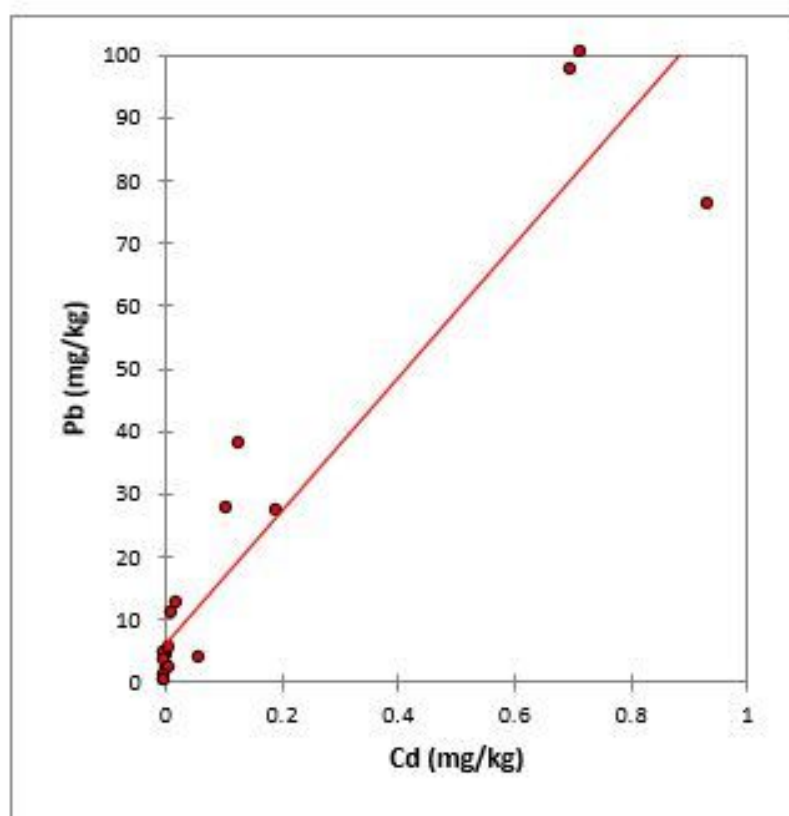

(a)

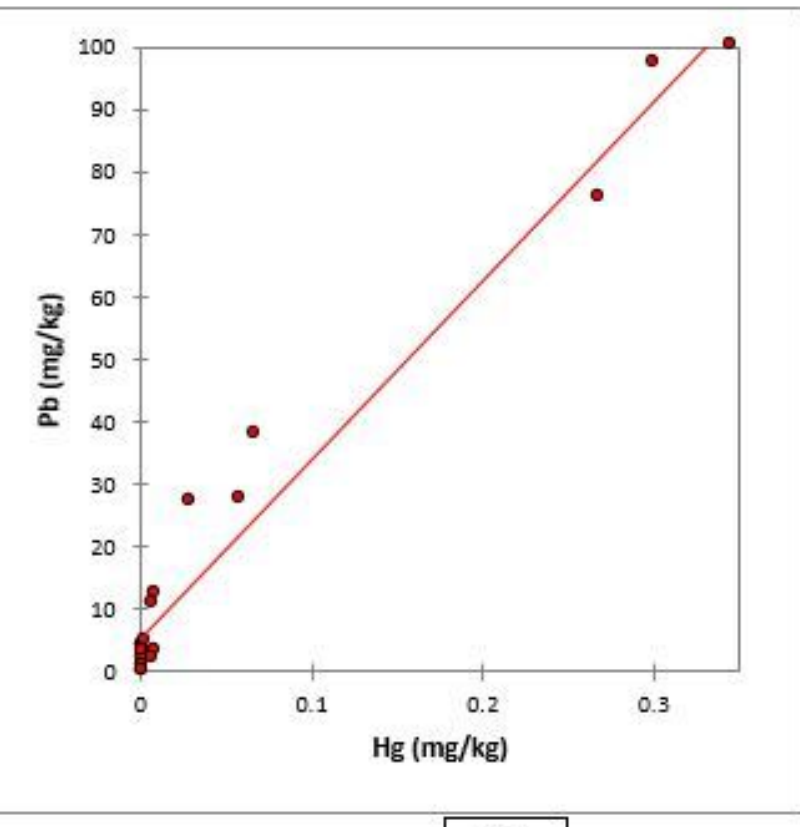

(b)

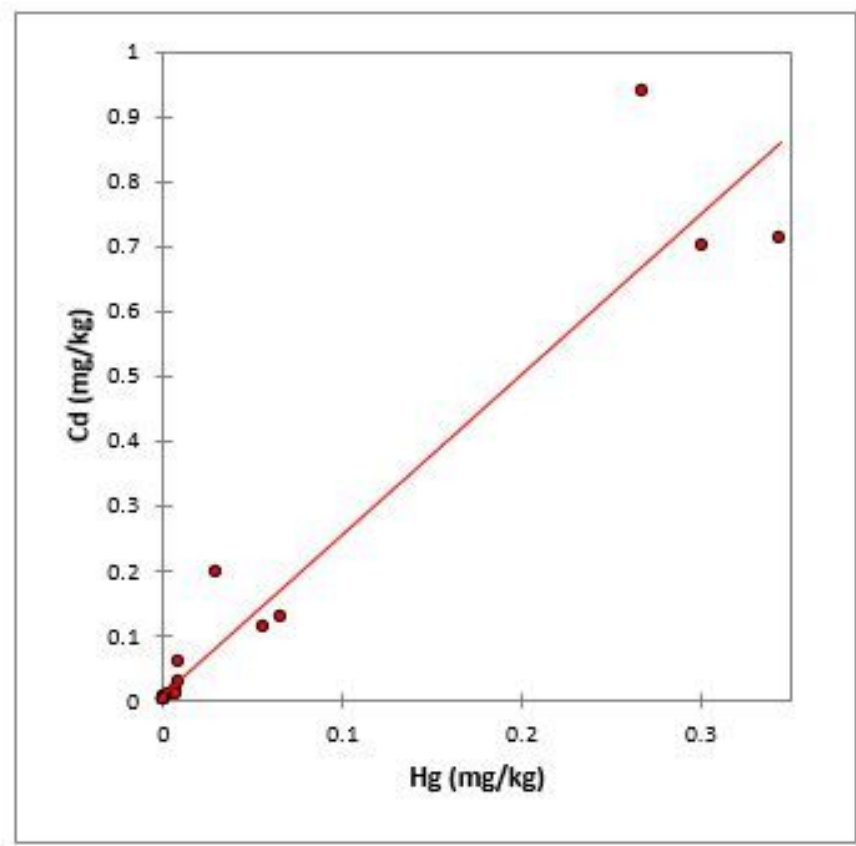

(c) 
Inter-trace metal correlation among trace metals in the liver of rats showed strong positive correlation ( $r>$ 0.90) between metals such as (a) $\mathrm{Cd}$ and $\mathrm{Pb}$ (b) $\mathrm{Hg}$ and $\mathrm{Pb}$ (c) $\mathrm{Hg}$ and $\mathrm{Cd}$ during the study. All correlations were significant at $p<0.01$.
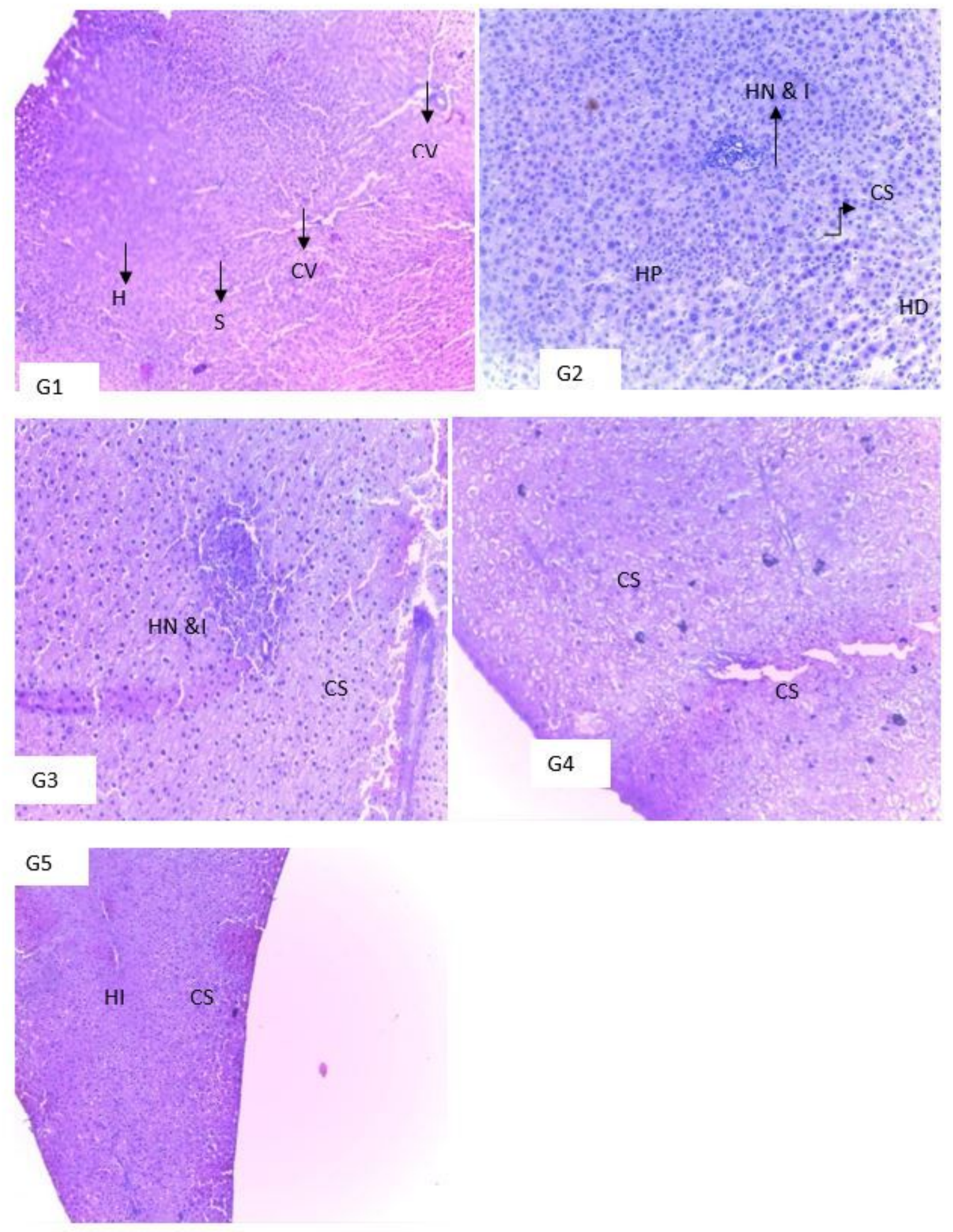

Figure 8

Histopathology of the liver: G1 (H20), G2 (TMM), G3 (TMM + $750 \mathrm{mg} / \mathrm{kg}$ ALECA), G4 (MM + $1500 \mathrm{mg} / \mathrm{kg}$ ALECA), G5 (TMM + $2250 \mathrm{mg} / \mathrm{kg}$ ALECA). Staining was done with haematoxylin and eosin magnification 
X 200 in all panels. CS (Cytoplasmic Swelling); HN \& I (Hepatocyte Necrosis and Inflammation); CV (Cytoplasmic Vacuolation); FC (Fatty change); HP (Hepatocyte Pleomorphism); HD (Hepatocyte Dysplasia); S (Sinusoids); H (Hepatocytes).

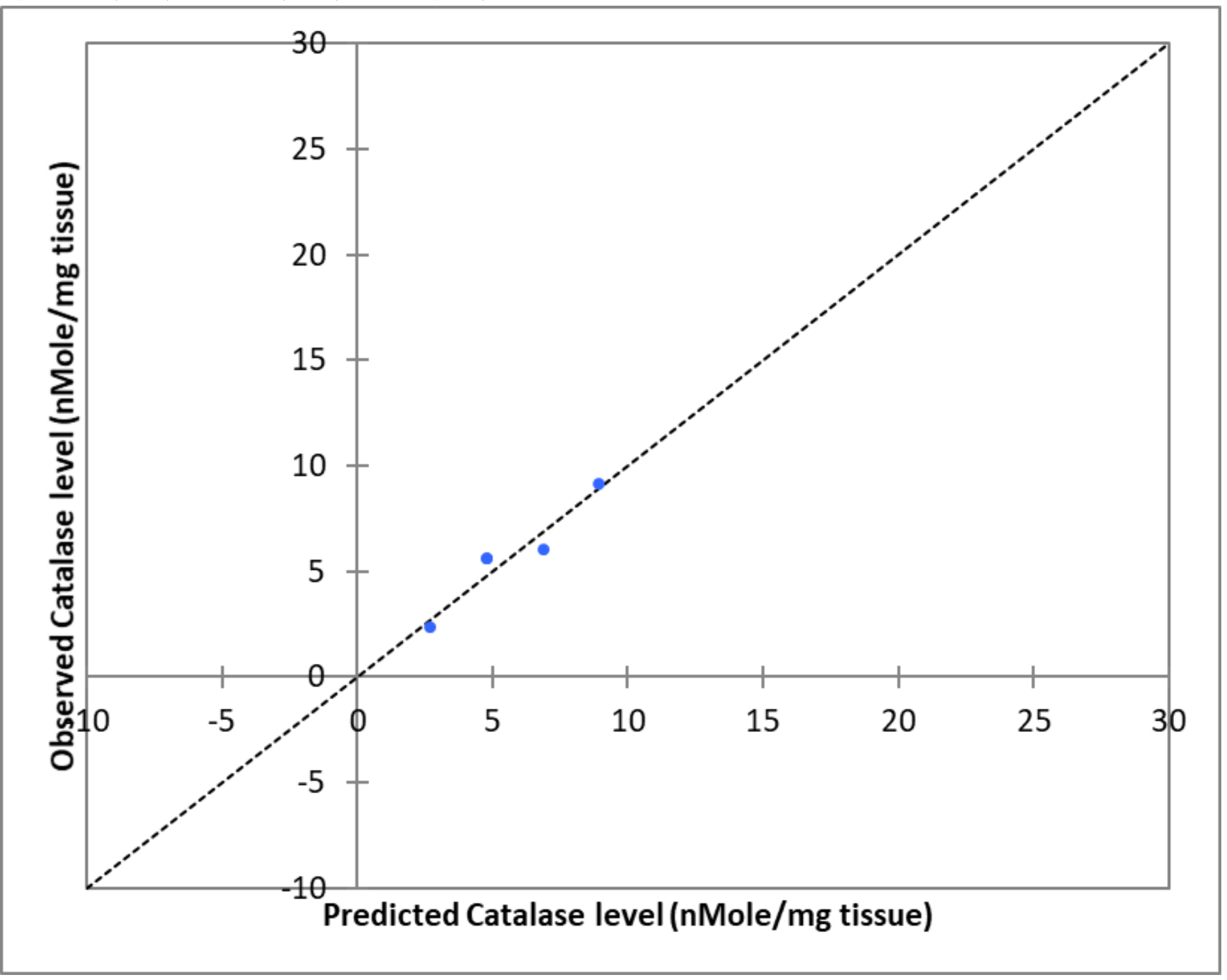

\section{Figure 9}

Predicted liver catalase level against observed liver catalase level (nMole/mg tissue); where $y=$ Catalase levels; $x=$ ALECA concentrations served as input values.

\section{Supplementary Files}

This is a list of supplementary files associated with this preprint. Click to download.

- GraphicalAbstract.jpg 